
Not for reproduction, distribution or commercial use.

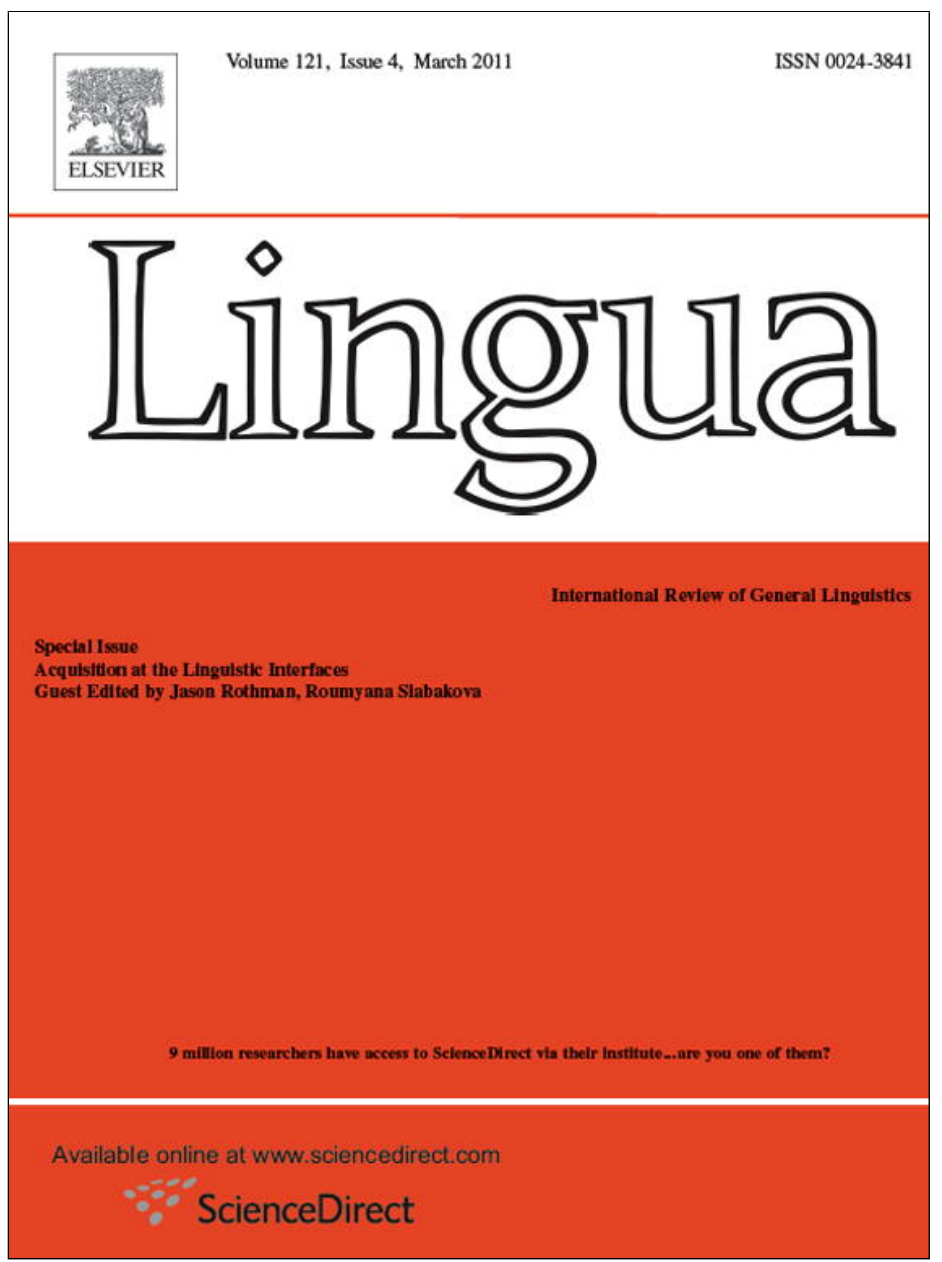

This article appeared in a journal published by Elsevier. The attached copy is furnished to the author for internal non-commercial research and education use, including for instruction at the authors institution and sharing with colleagues.

Other uses, including reproduction and distribution, or selling or licensing copies, or posting to personal, institutional or third party websites are prohibited.

In most cases authors are permitted to post their version of the article (e.g. in Word or Tex form) to their personal website or institutional repository. Authors requiring further information regarding Elsevier's archiving and manuscript policies are encouraged to visit:

http://www.elsevier.com/copyright 


\title{
L1 acquisition across Portuguese dialects: Modular and interdisciplinary interfaces as sources of explanation
}

\author{
Acrisio Pires ${ }^{1, a, *}$, Jason Rothman ${ }^{1, b}$, Ana Lúcia Santos ${ }^{1, c}$ \\ a University of Michigan, Linguistics, 458 Lorch Hall, 611 Tappan St, Ann Arbor, MI 48109-1220, United States \\ ${ }^{\mathrm{b}}$ University of Florida, United States \\ ${ }^{\mathrm{c}}$ Universidade de Lisboa, Portugal
}

\section{A R T I C L E I N F O}

\section{Article history:}

Received 8 December 2009

Received in revised form 3 June 2010

Accepted 3 June 2010

\section{Keywords:}

Acquisition

Change

Syntax

Portuguese

Infinitive

Inflection

\begin{abstract}
A B S T R A C T
This study investigates the child (L1) acquisition of properties at the interfaces of morphosyntax, syntax-semantics and syntax-pragmatics, by focusing on inflected infinitives in European Portuguese (EP). Three child groups were tested, 6-7-year-olds, 9-10-year-olds and 11-12-year-olds, as well as an adult control group. The data demonstrate that children as young as 6 have knowledge of the morpho-syntactic properties of inflected infinitives, although they seem at first glance to show partially insufficient knowledge of their syntaxsemantic interface properties (i.e. non-obligatory control properties), differently from children aged 9 and older, who show clearer evidence of knowledge of both types of properties. However, in general, both morpho-syntactic and syntax-semantics interface properties are also accessible to 6-7-year-old children, although these children give preference to a range of interpretations partially different from the adults; in certain cases, they may not appeal to certain pragmatic inferences that permit additional interpretations to adults and older children. Crucially, our data demonstrate that EP children master the two types of properties of inflected infinitives years before Brazilian Portuguese children do (Pires and Rothman, 2009a,b), reasons for and implications of which we discuss in detail. (c) 2010 Elsevier B.V. All rights reserved.
\end{abstract}

\section{Introduction}

Given two central questions of linguistic inquiry: What constitutes linguistic knowledge? and How is such knowledge learned/acquired?, it is reasonable to claim that the answer to either or both of these questions cannot be fully addressed solely by studying sub-parts of grammatical systems in isolation (e.g. phonology, syntax, semantics, and morphology). Studying the interaction between different levels of linguistic knowledge and their interface with non-linguistic cognitive domains has the promise of shedding a more explanatorily adequate light on these fundamental questions. This is true since sub-modules of linguistic systems and other areas of cognition not specific to language are somewhat dependent on each other, making the interaction between sound, structure and meaning possible. As part of the general effort to make more precise earlier conceptualizations of what constitutes the human language faculty, some contemporary work has maintained that the innate capacity for language can actually be captured under a relatively small number of core cognitive competencies, perhaps as few as one. Under the most economical of these proposals, the only core aspect of the language faculty consists of the ability to generate recursive structures by a computational mechanism provided universally, relegating remaining properties of language to the interfaces of this mechanism with other mental systems not

\footnotetext{
* Corresponding author. Tel.: +1 7346472156.

E-mail address: pires@umich.edu (A. Pires).

1 All authors contributed equally to this project.
} 


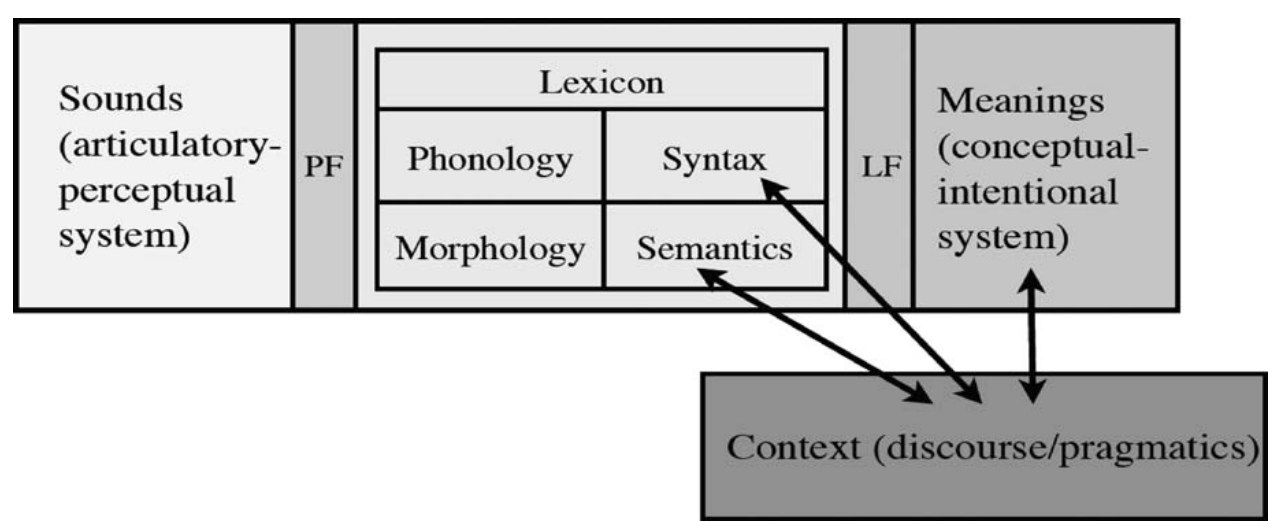

Fig. 1. Cognitive-linguistic interface design: White (2009).

exclusively devoted to language (see e.g. Jackendoff, 2002; Chomsky, 2005; Reinhart, 2006 and references therein). It is easy to appreciate the explanatory value of such proposals under the umbrella of a minimalist feature-based model of grammar, since under this general program the vast majority of linguistic properties are understood to involve the interaction of the grammar with two cognitive interfaces. It is currently argued that grammatical features are located within the particular grammar lexicon, thus implicating the lexicon-syntax interface. Since a large number of functional features are also encoded as part of inflectional morphology, they inherently involve the syntax-morphology interface. Formal features can be LF-interpretable and/or PF-interpretable, implicating the syntax-semantics and the syntax-morphology-phonology interface. Information structure regulates the distribution of linguistic properties linking discourse pragmatics at least with syntax and semantics. One need not look far to find grammatical properties that tangibly exemplify the abstraction of interface dependencies. For example, examining the full spectrum of referential pronominal subjects in languages such as Spanish and Portuguese may require invoking all of the abovementioned interface relationships.

Most acquisitionists working on interface properties do not strictly subscribe to any one particular version of cognitivelinguistic interface design, but draw on the conceptual similarities among existing models. Generative acquisitionists adopt the view that linguistic modules are interdependent with each other or with other cognitive systems. Combining insights from Chomsky (1995), Jackendoff (2002) and Reinhart's (2006) models, one can assume a general model that invokes linguistic interfaces as in Fig. 1, borrowed from White (2009).

The present study investigates the acquisition of inflected infinitives in European Portuguese (EP)(e.g. Raposo, 1987; Ambar, 1989; Madeira, 1994) child language acquisition, focusing on related properties at two distinct interfaces, namely morphosyntactic properties, and the syntax-semantic properties that result in the non-obligatory control interpretive properties of inflected infinitives (Pires, 2006). Data from two experiments will be presented from four groups of EP speakers: three child groups ages $6-7(n=24), 9-10(n=20)$ and $11-12(n=28)$, and a control group of adults $(n=32)$. At first glance it might not be immediately clear the reasons explaining why data were collected starting at the age of six and not earlier. As we further discuss in section 2, data collection began at 6 largely due to the relative complexity of the experimental tasks, also relating to previous research done on the acquisition of Brazilian Portuguese (BP) (Pires and Rothman, 2009a, 2010). Notwithstanding, our choice in age is justified by the data we present given that only a portion of the children at the age of 6 show knowledge equivalent to adults, regarding certain properties related to inflected infinitives. Based on this, we can assume that most, if not all, children younger than 6 would lack adult-like knowledge. Nevertheless, the data we present reveal that most children at the age of 6 demonstrate knowledge of the morpho-syntactic properties of inflected infinitives, and at least some of these children exhibit above chance performance regarding part of the syntax-semantic properties of non-obligatory control that characterize inflected infinitives. These data suggest that the acquisition of morpho-syntactic features in child language acquisition do not always result in evidence of immediate, concurrent acquisition of all properties associated with other linguistic interfaces. ${ }^{2}$ We will discuss implications of our data as it relates to research on interfaces in acquisition.

In the spirit of interfaces more generally defined, we will also address an interdisciplinary interface, that is, the link between empirical language acquisition studies and diachronic linguistics, analyzing the implications between the present study on EP child acquisition and the study of BP child acquisition in Pires and Rothman (2009a, 2010), in which it was demonstrated that BP children do not have proficient knowledge of the studied inflected infinitive properties at least until the age of 11. Pires and Rothman (2009a) argued that their data supported implicit acquisition predictions by the diachronic proposal that BP vernacular dialects no longer instantiate inflected infinitives (e.g. Pires, 2006, see also Lightfoot, 1991). Pires and Rothman argued that BP speakers show knowledge of inflected infinitives starting only at adolescence as the result of exposure to the standard BP dialect, primarily via formal education, and not as the result of acquisition of a colloquial dialect (see Rothman, 2007 and Pires and Rothman, 2009b for similar arguments for heritage speaker bilingualism). The results of the current study demonstrate that EP children display mastery of inflected infinitives years before BP

\footnotetext{
${ }^{2}$ Given the apparent asymmetrical acquisition of the tested properties (i.e. morpho-syntax before semantics) it would be relevant for future research to investigate in more detail the timing at which interface properties of inflected infinitives become active in EP L1 grammar.
} 
children, providing additional independent evidence in favor of the diachronic proposal for BP, as we discuss in section 6. Therefore, this study shows how investigating the acquisition of multiple dialects of the same language and comparing their properties and analyses can strengthen the formal relevance of the language change-acquisition interface.

\section{Previous related research}

Differently from the case of EP, major aspects of the formal/standard grammar of BP are argued to have been at least partially eliminated from colloquial dialects, such as third-person accusative clitic pronouns, post-verbal clitic pronouns (enclisis), subjunctive morphosyntax, null subjects and, crucially for this study, inflected infinitives (e.g. Cyrino, 1997; Roberts and Kato, 1993; Kato, 2005; Kato et al., 2009; Pires, 2002, 2006). For the case of inflected infinitives, alternative structures replace inflected infinitives in colloquial speech (i.e. finite clauses/non-inflected infinitives, e.g. Koike, 1983). Coupling this "avoidance" of inflected infinitive use with evidence from native informants, particularly not highly educated ones, prompted the argument that inflected infinitives have been partially or entirely eliminated from the grammar of colloquial BP (e.g. Lightfoot, 1991: 99-102; Pires, 2002, 2006), in sharp contrast to what is observed in the various dialects of European Portuguese (Raposo, 1987). Nevertheless, educated adult BP speakers demonstrate evidence of full knowledge of the grammatical properties of these forms (e.g. Quicoli, 1996; Rothman and Iverson, 2007; Rothman, 2009). It is argued that diachronic shift is masked on the surface as adult BP speakers who are educated come to learn these properties during the course of later acquisition of a particular grammar, namely standard BP, especially as the result of formal education and literacy (see Kato et al., 2009 for related arguments regarding clitics, under similar conditions).

The above scenario, as pointed out by Rothman (2007), makes different acquisition predictions, in particular: (a) BP children should demonstrate late acquisition of these properties in general, especially in comparison to EP children and (b) most heritage speaker BP bilingual adults should show target deviant knowledge for these properties while EP heritage speakers should not, at least not to the same degree. Although the combination of Rothman's (2007) BP heritage speaker data with Pires and Rothman's (2009b) data for EP confirm prediction (b), prediction (a) could not previously be confirmed or falsified regarding the comparison to child EP. Coupling the present data with the case of L1 BP data will allow us to argue that prediction (a) is also confirmed.

Pires and Rothman (2009a) presented results from a cross-section of 87 upper-income BP children/teenagers (ages range from 6 to 15) using the same methodology we employ for the present study (modified here for dialectal differences). ${ }^{3}$ They showed that, with very few individual exceptions, BP children show adult-like knowledge of the syntax and semantics of inflected infinitives starting only at the age period of 10-12, after which they perform like the expected adult norms, more or less without exception. Interestingly, the acquisition of the morpho-syntactic properties and the semantic properties of nonobligatory control cluster somewhat uniformly among the older child BP learners, partially differently than what we will report for the case of EP. Pires and Rothman concluded that proficient acquisition of inflected infinitives in BP occurs very late (from age 10 on), when compared to other aspects of morphosyntax and syntax-semantics, and only upon sufficient exposure to the standard dialect, which by all accounts instantiates inflected infinitives, consistent with predictions of proposals of diachronic change in BP. However, their data is only consistent with such proposals, as they acknowledge. Whereas comparative evidence from other sets of learners such as heritage language bilinguals has lent support to their conclusion (Pires and Rothman, 2009b), it is still possible that diachronic change is not the only factor at play if child acquisition of inflected infinitives were simply a late-acquired property in general. A crucial question arises as to whether inflected infinitives have properties that are not easily learnable, making them a later acquired property in general, limiting the hypothesized connection to diachronic change. Pires and Rothman (2009a) could not preclude this possibility without independent comparative evidence. However, the current study will show, among other results, that Pires and Rothman's claims are strongly supported, given the independent results from child EP we present here.

\section{Inflected infinitives: at the morpho-syntax and syntax-semantics interfaces}

Portuguese has two types of infinitives, which are primarily distinguished by either carrying person/number agreement (inflected infinitives) or not (uninflected infinitives). European Portuguese and Standard Brazilian Portuguese are distinct regarding which person/number forms they display for inflected infinitives, ${ }^{4}$ but both dialects display distinct forms at least for 1 st and 3rd plural inflected infinitives, as in (1):

$$
\begin{array}{ll}
\text { nós sai-r-mos } & \text { vocês/eles/elas saí-r-em } \\
\text { we leave-INF-AGR.1PL } & \text { you.pl./they leave-INF-AGR.3PL }
\end{array}
$$

Inflected infinitives act like normal finite clauses and unlike uninflected infinitives regarding certain morpho-syntactic properties. Besides showing overt person/number agreement, inflected infinitives, unlike uninflected infinitives, allow overt

\footnotetext{
${ }^{3}$ Pires and Rothman (2010) present follow-up results from an additional group of 35 upper-income teenagers (age 10-15) who were tested by means of oral comprehension, as in this study, further confirming the results obtained in Pires and Rothman (2009a), in which 10-15-year-old were tested through written comprehension.

${ }^{4}$ EP also has inflected infinitival forms for 2nd person: the singular (tu saí-r-es 'you.SG leave-INF-2SG') is actively used whereas the plural form (vós sai-rdes 'you.PL leave-INF-2PL') is no longer actively used.
} 
subjects in non-Exceptional Case Marking contexts (2). In addition, differently from their uninflected counterparts, inflected infinitives cannot occur as complements of certain predicates, such as volitional verbs (3) and verbs like tentar 'try' and conseguir 'manage'.

É necessário eles pararem de ver televisão agora.

is necessary they stop.INF.3PL of see.INF television now

'It is necessary for them to stop watching TV now.'
*O Paulo e o David querem irem ao parque.
the Paulo and the David want go.INF.3PL to-the park
'Paulo and David want to go to the park.'

However, inflected infinitives are different from finite forms and partially similar to uninflected infinitive clauses in that they are never introduced by the complementizer que 'that' (4) and must occur in embedded clauses (5) (see Pires, 2006; Pires and Rothman, 2009a $)^{5}$ :

$$
\begin{aligned}
& \text { a. } \quad \text { É possível que eles chegarem agora. } \\
& \text { pro is possible that they arrive-INF-3PL now } \\
& \text { 'It is possible that they arrive now.' }
\end{aligned}
$$

$$
\begin{aligned}
& \text { b. } \quad \text { Eles chegarem agora. } \\
& \text { they arrive-INF-3PL now }
\end{aligned}
$$

'They to arrive now.'

Regarding their syntax-semantics properties, inflected infinitives take null subjects (pro) or lexical subjects with nonobligatory control properties, whereas uninflected infinitives can only take PRO null subjects, which in various contexts must carry obligatory control interpretation (e.g. Pires, 2006; Quicoli, 1996; Raposo, 1987; Ambar, 1989). As a result of this distinction, at least three contrasts have been shown to arise sharply between the two forms for native speakers who show knowledge of inflected infinitives, both in BP (Pires and Rothman, 2009a, 2010) and EP(Pires and Rothman, 2009b). First, the null subject (pro) of inflected infinitives may be disjoint in reference from any DP in the sentence (6a), whereas the null subject(PRO) of uninflected infinitives must have a local c-commanding antecedent when it occurs as complement or adjunct clauses (6b). ${ }^{6}$

$$
\begin{aligned}
& \text { a. [O meu pai }]_{\mathrm{i}} \quad \text { lamentou } \text { pro }_{\mathrm{k} /{ }^{*} \mathrm{i}} \text { perdermos a carteira. } \\
& \text { [The my father] }]_{\mathrm{i}} \quad \text { regretted } \text { pro }_{k /{ }^{*} \mathrm{i}} \text { lose-INF-1PL the wallet } \\
& \text { 'My father regretted our losing our wallet.' }
\end{aligned}
$$

\footnotetext{
${ }^{5}$ As pointed out by Pires and Rothman (2009b), inflected infinitives can only occur in a restricted set of root clauses, adult root infinitive (RI) contexts also referred to as Mad Magazine sentences (Akmajian, 1984).

(i) Eles irem ao cinema !? Impossível.

They go-INF-3PL to-the movies!? Impossible

'Them go to the movies!? Impossible.'
}

Madeira (1994:186) also states that inflected infinitives are possible as root exclamatives in EP, but does not analyze them. However, there are substantial constraints on the syntax and semantics of adult RIs. Grohmann and Etxepare (2003), for instance, argue that RIs, e.g. in English and Spanish, are actually embedded in an Exclamative Phrase (ExclP) that also includes the coda ('impossible' in (i)), yielding a modal interpretation that is absent from regular infinitival clauses. These constraints on adult RI also rule out indicative and subjunctive clauses in such contexts, distinguishing them from standard finite clauses. Martins (in press) shows that inflected infinitives occurred in other root contexts in Old Portuguese, different from Modern Portuguese, in examples that she glosses as indicating deontic necessity (see also Martins, 2001).

${ }^{6}$ There are differences between infinitives in BP and EP that were not targeted in the experiments considered here. For instance, even though colloquial BP no longer productively instantiates inflected infinitives, it has developed the possibility of overt nominative subjects with non-inflected infinitives, differently from Standard BP and from EP in general (see Pires, 2006, chap. 4 for extensive analysis):

(i) 0 Pedro pediu para eles sair (colloquial $\mathrm{BP} /{ }^{*}$ Standard $\mathrm{BP} /{ }^{*} \mathrm{EP}$ )

the Peter asked for they leave-INF

'Peter asked them to leave.'

In addition, as a reviewer points out, even when Brazilians acquire the inflected infinitive, they differ from Europeans by realizing the subject overtly in a wider range of cases (ii). However, null subject pro is possible in Standard BP (see Pires, 2006, chap. 3), and even colloquial BP still displays null subjects in a restricted set of finite domains (see e.g. Figueiredo Silva, 1996; Rodrigues, 2004):

(ii) $\mathrm{O}$ Pedro pediu para eles saírem. BP (vs. pediu para saírem EP)

The Pedro asked for they leave-INF-3PL (vs. asked for leave-INF-3PL

'Peter asked them to leave (vs. asked (them) to leave)'

Pires and Rothman (2010:375-376) provide several arguments indicating that null subject pro (or lack thereof) was not an interfering factor in their experimental results regarding the acquisition of infinitives in BP. 
b. $\quad[\mathrm{Os} \text { meus pais }]_{\mathrm{i}}$ lamentaram $\mathrm{PRO}_{\mathrm{i}} /{ }^{*} \mathrm{k}$ perder a carteira.

[The my parents $]_{\mathrm{i}}$ regretted $\quad \mathrm{PRO}_{\mathrm{i}} /{ }^{*} \mathrm{k}$ lose-INF the wallet

'My parents regretted losing their wallet.'

Second, Pires (2006) argued that uninflected infinitives require a sloppy reading under ellipsis in examples such as (7a), whereas inflected infinitives only allow a strict interpretation of the ellipsis site, as in (7b). ${ }^{7}$ With uninflected infinitives as in (7a), the elided material can only correspond to 'Rui regrets his own crying,' in which the interpretation of the null subject in the ellipsis site is 'sloppily' determined by the local antecedent (Rui) in the second conjunct. This is distinct from inflected infinitives as in (7b), for which the elided material must correspond to 'Rui regretted our crying', in which the null subject in the ellipsis site is strictly established as part of the antecedent of the ellipsis in the inflected infinitive clause.

a.

A Maria tinha lamentado ter chorado e o Rui também tinha.

the Maria $a_{i}$ had regretted $\mathrm{PRO}_{\mathrm{i} /{ }^{*} \mathrm{j}}$ have-INF cried and the Rui too had

(= Rui regretted having cried)

'Maria had regretted having cried and Rui had too.'

b. A Maria tinha lamentado termos chorado e o Rui também tinha.

the Maria ${ }_{\mathrm{i}}$ had regretted pro $_{\mathrm{k}}$ have-INF-1PL cried and the Rui too had

(= Rui regretted our crying)

'Maria had regretted our having cried and Rui had too.'

Third, Pires (2006) argued that inflected and uninflected infinitives can differ as to whether they allow (or not), only on the basis of syntactic features, split antecedents for embedded clause null subjects. In (8a), PRO does not allow an interpretation where $E u$ 'I' and Leo can form a set that serves as its antecedent. Conversely, in ( $8 \mathrm{~b}$ ), the embedded pro must be co-referential with a set of elements that includes, at the very least, eu 'I' and Leo. Given the plural agreement morphology of the inflected infinitive, its null subject pro cannot be co-referential with Leo only.

a.
$\mathrm{Eu}_{\mathrm{i}}$ convenci o $\mathrm{Leo}_{\mathrm{j}} \mathrm{PRO}_{\mathrm{j} /{ }^{*} \mathrm{i}+\mathrm{j}}$ a dividir o sorvete com o João.
$\mathrm{I}_{\mathrm{i}}$ convinced the $\mathrm{Leo}_{\mathrm{j}} \mathrm{PRO}_{\mathrm{j} /{ }^{*} \mathrm{i}+\mathrm{j}}$ to share-INF the ice-cream with the João
'I convinced Leo to share the ice cream with João.'

b. Eu $u_{\mathrm{i}}$ convenci o Leo $_{\mathrm{j}} \mathrm{pro}_{\mathrm{i}+\mathrm{j} /{ }^{*} \mathrm{j}}$ a dividirmos o sorvete com o João.

$\mathrm{I}_{\mathrm{i}} \quad$ convinced the $\mathrm{Leo}_{\mathrm{j}} \mathrm{PrO}_{\mathrm{i}+\mathrm{j} /{ }^{*} \mathrm{j}}$ to share-INF-1PL the ice-cream with the João

'I convinced Leo for us to share our ice cream with João.'

In the experiments that we carried out for this study, we investigate to which extent monolingual EP children (and adults we tested as controls) acquire knowledge of the contrasts above between inflected and non-inflected infinitives.

Following a minimalist approach to the specification of morpho-syntactic and semantic distinctions, we take the contrast between inflected and uninflected infinitives to follow from the feature specification of their functional heads. We adopt here the approach proposed in Pires (2006), according to which infinitives in general lack a feature specification for mood, different from subjunctives and indicatives (see e.g. Zanuttini, 1997:127). Given this, children need to identify in their primary linguistic data (PLD) that infinitives lack a mood specification in order for these forms to be possible in their grammars.

However, the lack of a feature specification for mood is not enough to trigger a grammar that also allows inflected infinitives. In scanning the PLD children also need to be able to identify phi-feature (i.e. agreement) specifications for infinitival forms carrying either the feature specification in (9) or in (10), corresponding to the two types of infinitives that are possible in Portuguese (adopting the proposal in Pires, 2006). In the case of inflected infinitives, the feature specification [+phi] maps to overt inflectional morphology, ${ }^{8}$ which can also be found separately from the main verb, in an auxiliary or a modal verb (in complex verb forms):

Phi-feature specification for inflected infinitives:

$$
\text { [T [+phi]] }
$$

Where [+phi] represents $\mathrm{T}$ with inflection for person and/or number.

Phi-feature specification for non-inflected infinitives:

$$
\text { [T [-phi]] }
$$

Where [-phi] represents $\mathrm{T}$ without inflection for person and/or number.

\footnotetext{
${ }^{7}$ This partially corresponds to a parallelism requirement on the interpretation of elided material (see e.g. Santos, 2009a,b for discussion).

${ }^{8}$ However, 1 st and 3rd person singular inflected infinitives do not carry overt person/number inflection. For this reason, the tests in this study used 1 st and 3rd person plural forms of inflected infinitives.
} 
Pires (2006) argues that the agreement/phi-features of inflected infinitives are responsible for their licensing both of overt subjects and of null subject pro with non-obligatory control properties, whereas the lack of these features forces uninflected infinitives to take only null subject PRO, which displays obligatory control properties in the corresponding cases in (6)-(8). In what follows we present the result of experiments testing the acquisition of the properties in this section by European Portuguese children and adolescents, as compared to adults.

\section{Methodology}

In order to assess children's knowledge of inflected infinitives, we replicated with European Portuguese children, adolescents and adults the tests used by Pires and Rothman (2009a,b, 2010). Testing included two tasks: a Grammaticality Judgment Task, which Pires and Rothman (2009a) call a Morphological Recognition Task (MRT), and an Interpretation Matching Task (IMT). The MRT task tested pure syntactic or morpho-syntactic properties of inflected infinitives, basically their morphology and syntactic distribution; the IMT task tested interpretation properties (syntax/semantics) of inflected infinitives.

The MRT/GJT investigated the extent to which the participants demonstrated a clear and distinctive command of finite morphology, and of the effects of the distinction between inflected and uninflected infinitival morphology on the syntactic distribution of the two types of infinitives. This test involved 12 stories: 6 stories testing inflected infinitives, 3 filler/control stories testing non-inflected infinitives and 3 filler/control stories testing present tense. After each story the child was asked to correct the test sentences, if they thought it was incorrect (each story was followed by two test sentences). For the younger children (up to age 9-10), the test sentence was uttered by a puppet, Tigger, given that children were told that Tigger was still learning Portuguese, and sometimes needed help when he made mistakes. Children up to age 9-10 were also shown one picture matching the story and one picture matching each test sentence, as they were presented. In (11) we present an example of a story followed by the two test sentences. Subjects were required to either accept or reject each test sentence as correct. In case they rejected the sentence, they were expected to provide a correction (possible corrections could target the verb forms present indicative, inflected infinitive and noninflected infinitive).

(MRT/GJT/Story testing inflected infinitive)

A Margarida e a Minie gostam de fazer desporto. Fazem natação, mas hoje o desporto delas é outro. Porque é que a escolha delas mudou?

Daisy and Minnie like sports. They always swim, but today they picked a different sport. Why did their choice change?

Test sentences (uttered by puppet, for younger subjects):

a. $\quad$ *É muito difícil elas nadar todos os dias.

It is very difficult they swim every day. (incorrect non-inflected inf. form)

b. $\quad$ Agora é mais importante a Margarida e a Minnie correrem mais.

Now it is more important for Daisy and Minnie to run more. (correct infl. inf)

(11)

a.

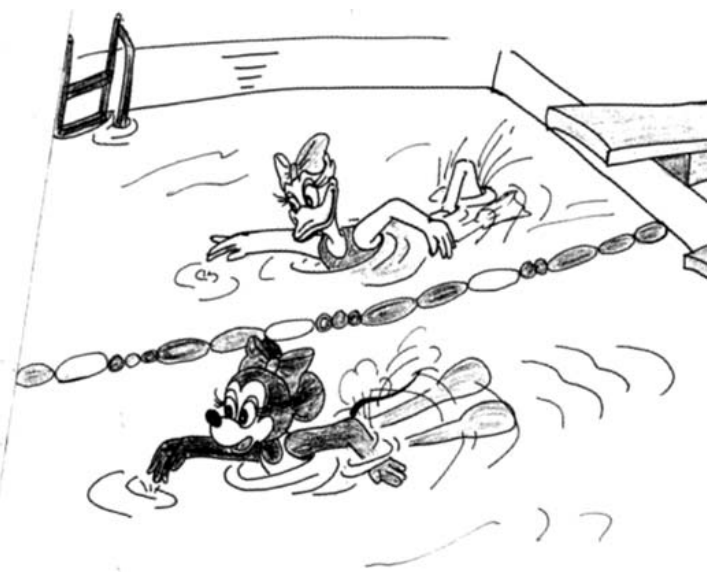

b.

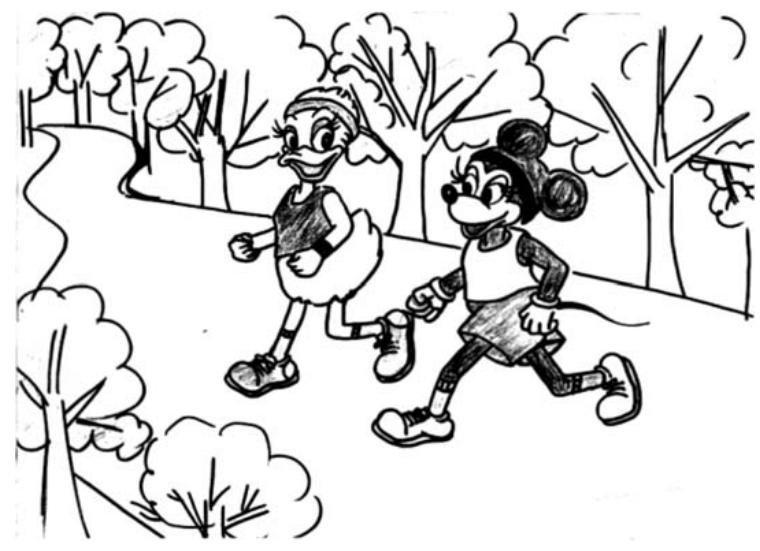

The Interpretation Matching Task (IMT) was developed to assess subject's interpretation of sentences with inflected and non-inflected infinitives, targeting the postulated contrasts between obligatory and non-obligatory control in (6)-(8). In the case of younger subjects (up to age 9-10), the task was presented as a sentence-picture matching task. Although asked to choose one of the pictures/interpretations, participants were also given the option to indicate if their interpretation of a target sentence did not match either picture/description. There were 24 stories, 12 including a test sentence with inflected 
infinitives, 6 using a test sentence with non-inflected infinitives (used for control), and 6 using a filler/distracter sentence. A test item is presented in (12). ${ }^{9}$

O Mickey estava em casa com o Pato Donald e a Margarida. O carro estava muito sujo e precisava de uma limpeza. 'Mickey was at home with Donald Duck and Daisy. The car was very dirty and needed cleaning.'

Test sentence with inflected infinitive:

O Mickey ficou satisfeito por lavarem o carro.

the Mickey was happy for wash-INF-3PL the car

'Mickey was happy that (they) washed the car.'

a. Wrong picture/sentence description (obligatory control interpretation)

O Mickey lavou o carro sozinho.

'Mickey washed the car alone.'

b. Correct picture/description (Non-obligatory control interpretation)

O Pato Donald lavou o carro juntamente com a Margarida.

'Donald Duck washed the car with Daisy.'

(12)

a.

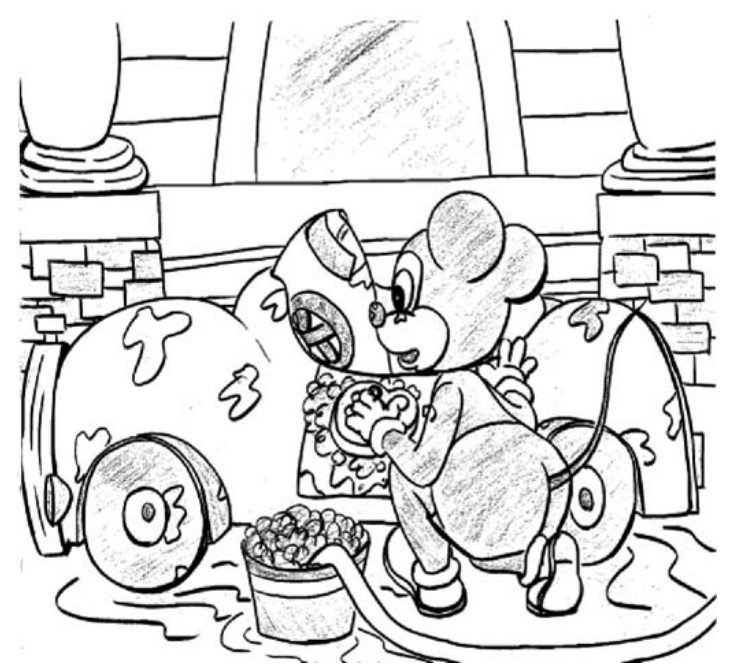

b.

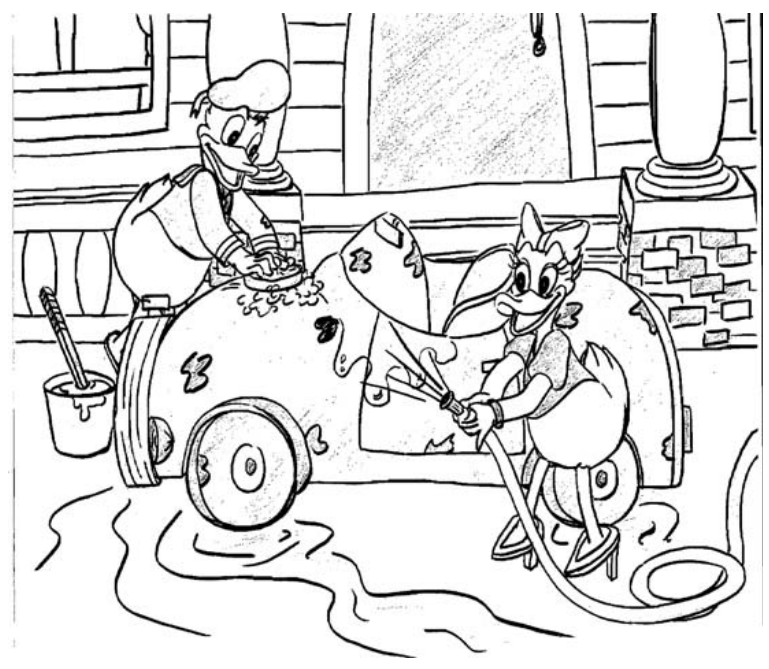

Stories tested for the properties taken to distinguish obligatory vs. non-obligatory control: (i) (non)-obligatory control/(lack of) a c-commanding antecedent (as in the previous example), (ii) strict/sloppy reading under ellipsis and (iii) split/non-split antecedent.

We tested three groups of children and adolescents: 24 6-7-year-olds; 20 9-10-year-olds and 28 adolescents ages 11-12. The adolescents and the children belong to the same group of schools in a suburban area near Lisbon (Amadora). We also tested a control group of 32 adults, all undergraduate students at the University of Lisbon without background in linguistics. In the statistic treatment of the data, a repeated-measures ANOVA was performed (alpha $=.05$ for a confidence level of $95 \%$ ), followed by Sidak post hoc tests.

\section{Results}

\subsection{MRT}

The results obtained in the MRT task are presented in Figs. 2 and 3. Fig. 2 shows the results for the test conditions that were expected to be recognized as grammatical by different speakers. All the age groups showed performance at ceiling or close to ceiling regarding acceptance of correct forms (Fig. 2).

\footnotetext{
${ }^{9}$ The child task used Disney characters as they are called in EP (Mickey, Pato Donald 'Donald Duck', etc.) and the adult/teenager task (which used sentences describing the target interpretations, instead of pictures) used proper names in EP (e.g. Miguel, Ronaldo, etc.). Part of the correct or incorrect descriptions (i.e. paraphrases) of the test sentences presented to the teenagers/adults had verbs in the singular form (12a,b) so that participants were not biased by verb plural inflection into choosing the description with a plural referent (e.g. Mickey alone vs. Donald Duck and Daisy together), which would match the plural inflected infinitives used in the experiment.
} 


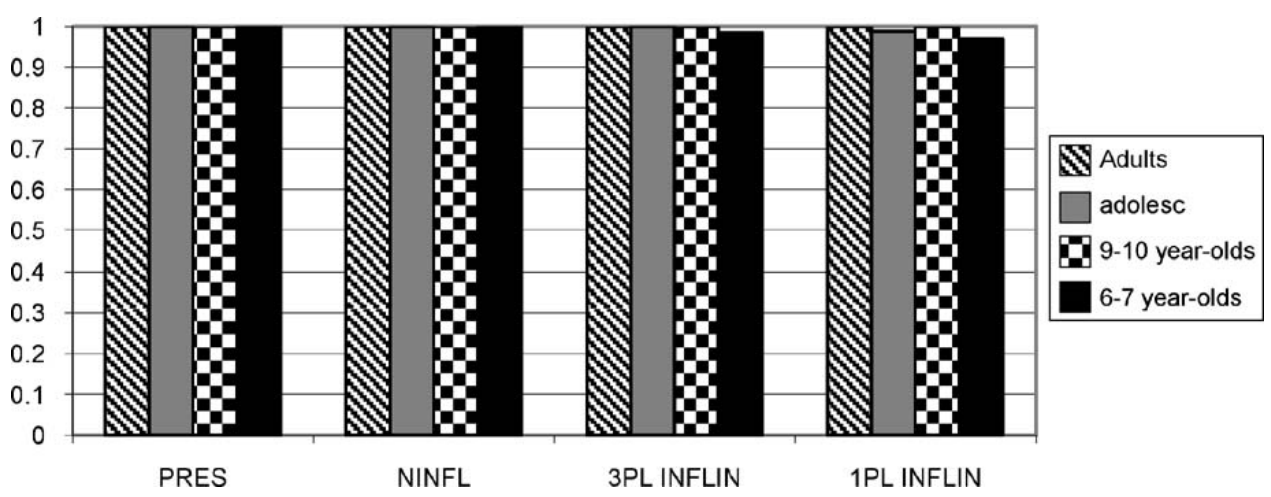

Fig. 2. MRT task-results (acceptance expected). PRES: present tense; NINFL: non-inflected infinitive; 3PL INFLIN: 3rd plural inflected infinitive; 1PL INFLIN: 1st plural inflected infinitive.

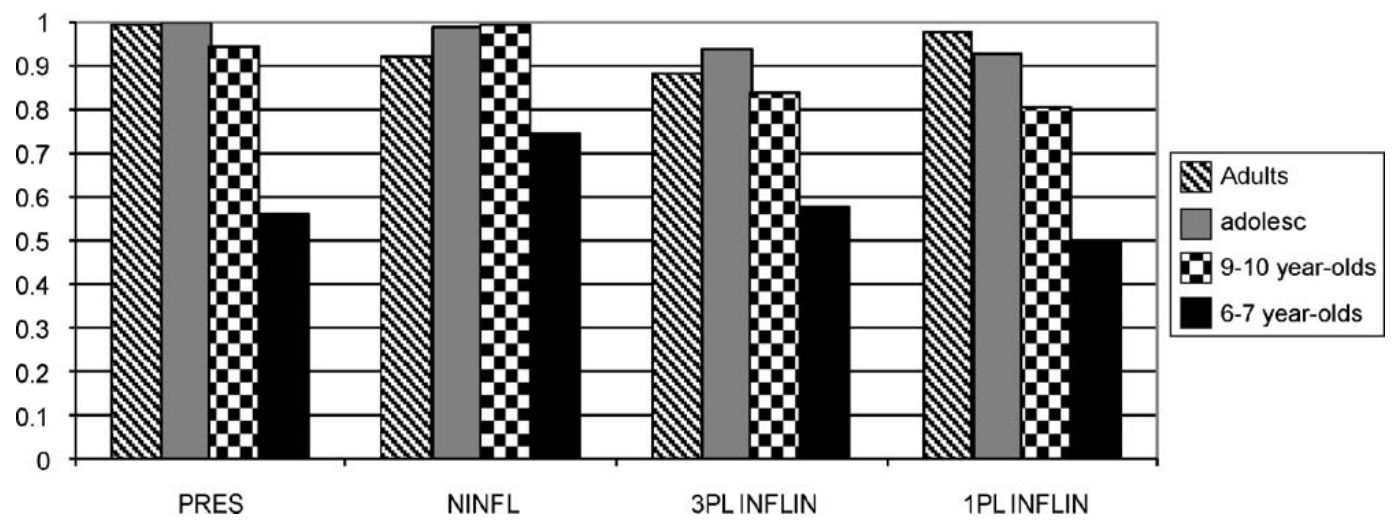

Fig. 3. MRT task-results ("fix" conditions-correction expected). PRES: present tense; NINFL: non-inflected infinitive; 3PL INFLIN: 3rd plural inflected infinitive; 1PL INFLIN: 1st plural inflected infinitive.

Fig. 3 shows the relevant cases for us, in which participants had to identify the ungrammatical sentences ("fix" conditions). ${ }^{10}$ Crucially, these were the only cases in which the subjects showed distinct behavior across age groups, and we will only refer to these cases in the discussion of the results below.

An intergroup comparison between each of the groups and adolescents shows that 6-7-year-olds are significantly different $(p=.000$ ) from the other groups in the "fix" conditions involving infinitives (inflected and non-inflected); 9-10year-olds significantly differ from adolescents only in the 1st plural inflected infinitive "fix" condition; there are no significant differences between adolescents and adults.

Subjects in the younger group showed some difficulty with the MRT task per se-three 6-7-year-olds were excluded from this task as cases of yes-biases. The fact that the task itself was difficult for the younger children may be reflected in the results with sentences targeting the present tense, in which these subjects performed only slightly better than at $50 \%$. Considering the "fix" items with inflected infinitives (3rd plural and 1st plural), we can see that 6-7-year-olds obtained similar results, slightly more than or around $50 \%$. This could indicate chance and, therefore, absence of proficient knowledge of inflected infinitives. However, there are clear individual differences, so group average results around 0.5 are not necessarily chance level results (at least not for all individuals): 10 subjects were above chance and 9 subjects below chance. Therefore, about half of the 6-7-year-olds do indeed show knowledge of the morphology and the syntactic distribution of inflected infinitives.

The other relevant fact to be highlighted here is that adults exemplified unexpectedly worse results with 3rd plural inflected infinitives than in other conditions. In fact, these unexpected results are explained by bad results in particular items, namely, the overacceptance of querem irem 'want to.go-3PL' (11 out of 32 subjects), i.e. an inflected infinitive selected by a volition verb. A difficulty with the same test item (querem irem) was observed in the 910-year-old group (7 out of 20). 9-10-year-olds also overaccepted certain 1PL forms (conseguimos acharem '(we) managed to.find-3PL' and tentámos comprarmos '(we) tried to.buy-1PL'), although at lower rates. We return to this in section 6 .

\footnotetext{
${ }^{10}$ We counted as appropriate answers all cases in which participants were able to identify the ungrammatical sentences, independently of whether they were able to provide an appropriate correction for them. The graphs are based on means across subjects.
} 


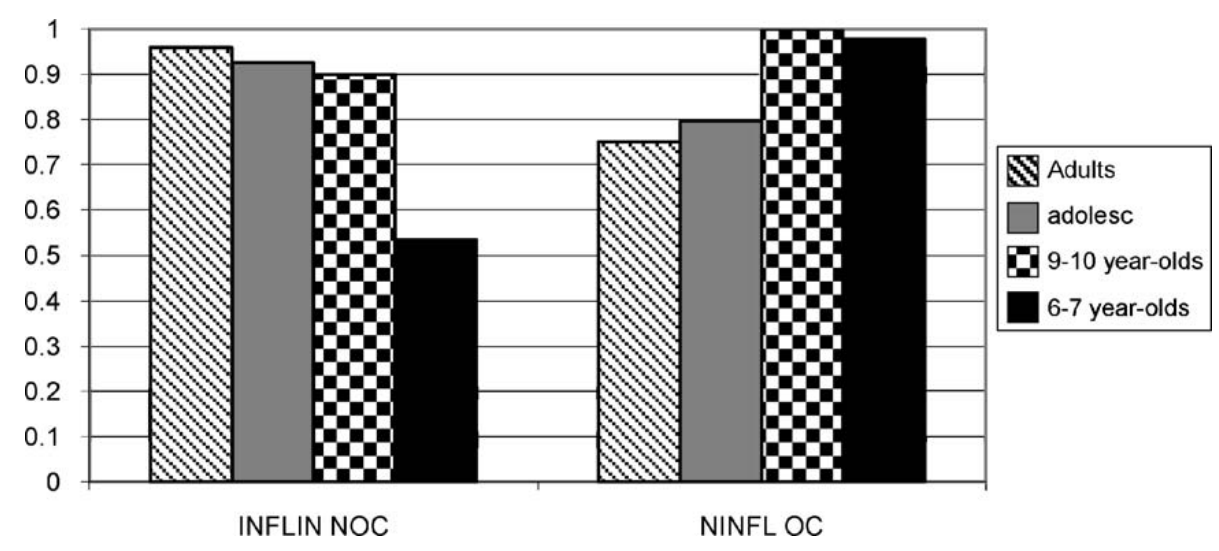

Fig. 4. IMT task-control condition. INFLIN NOC: inflected infinitive, non-obligatory control; NINFL OC: non-inflected infinitive, obligatory control.

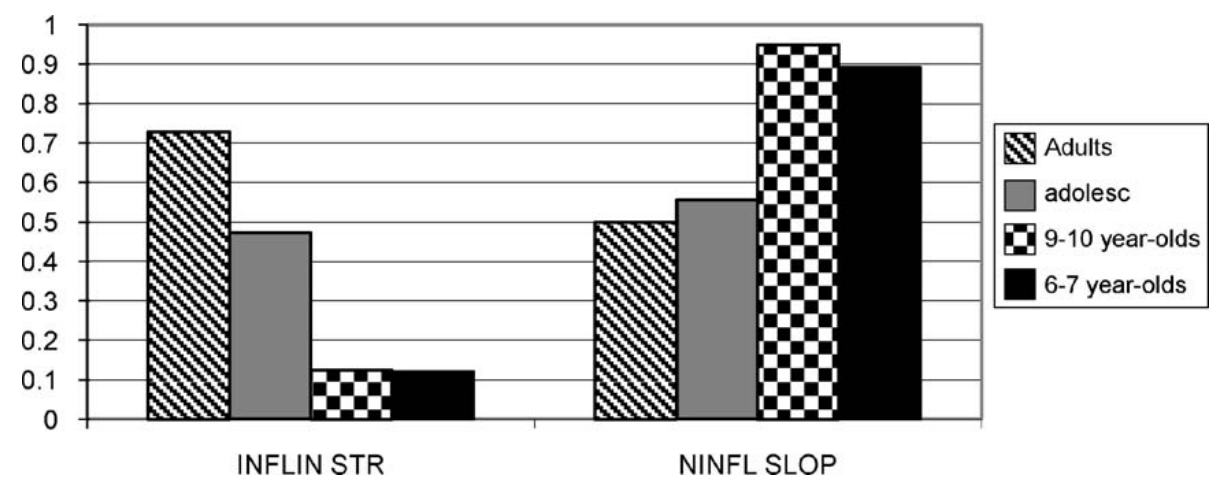

Fig. 5. IMT task-strict/sloppy reading condition. INFLIN STR: inflected infinitive, strict reading; NINFL SLOP: non-inflected infinitive, sloppy reading.

\subsection{IMT}

The general results of the IMT task are presented in Figs. 4-6.

The control condition: First, looking at the results of items with inflected infinitives corresponding to non-obligatory control (INFLIN NOC) readings (Fig. 4), we can see that there is clear growth of correct results with age and, clearly, 9-yearolds have such knowledge of inflected infinitives. There was no significant difference between adults and 9-year-olds ( $p=0.95$ ) or between adolescents and 9-year-olds ( $p=0.999)$. However, the difference between the 6-7-year-olds and 9year-olds as a group is significant $(p=0.000)$.

Again, the 6-7-year-old group presents average results at around 0.5. As it happened in the MRT results, these results look like chance-level results but they are not. Considering individual results, some subjects are below chance but, crucially, others are at ceiling ( 8 below chance; 10 above chance and, among these, 6 at ceiling). This indicates that at least some 6-7year-olds clearly acquire this aspect of the syntax-semantics of inflected infinitives.

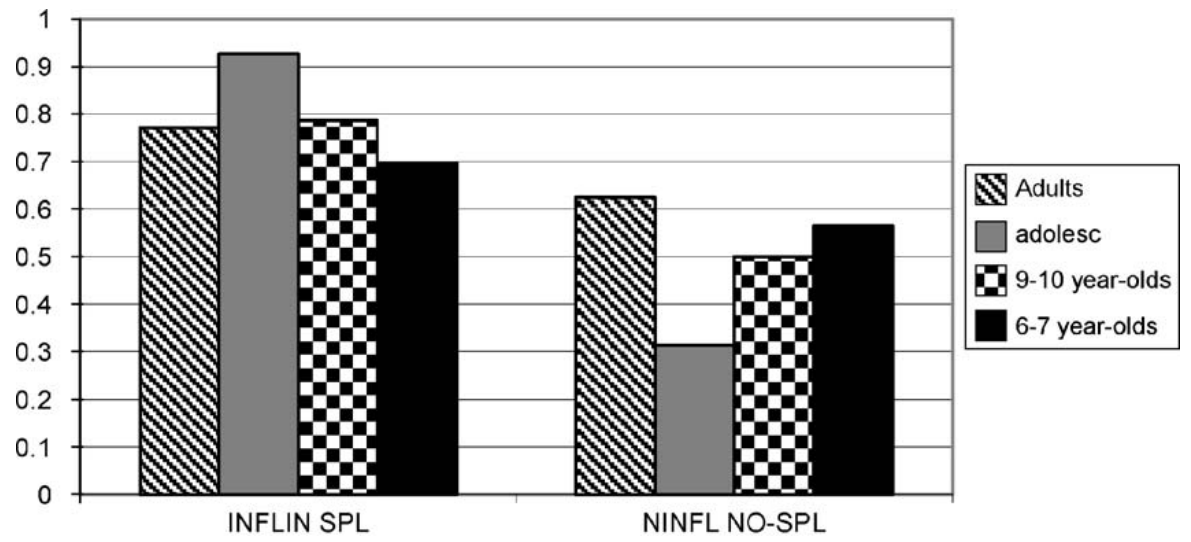

Fig. 6. IMT task-split/non-split antecedent condition. INFLIN SPL: inflected infinitive, split antecedent; NINFL NO-SPL: non-inflected infinitive, non-split antecedent. 
Considering now the condition testing obligatory control with non-inflected infinitives (NINFL OC), the results show that adults and adolescents seem to perform worse than expected and, especially, worse than children. In (13) we see one of two test items that were considered for this $\operatorname{condition}^{11}$ :

Story: O Miguel, a Margarida e a Sílvia foram ao centro comercial. A Margarida e a Sílvia gostam das compras. O Miguel disse que estava um filme óptimo em cartaz no cinema do centro comercial.

'Miguel, Margarida and Sílvia went to the mall. Margarida and Sílvia like shopping. Miguel said that there was an excellent movie at the mall movie theater.'

Test sentence:

A Margarida disse depois: $\quad 0$ Miguel adorou ter visto um filme.

the Margarida said later the Miguel loved have-INF seen a movie

'Margarida said later: Miguel loved to have seen a movie.'

Description choices:

a. $\quad$ O Miguel viu o filme sozinho.

'Miguel saw the movie alone'.

b. A Margarida viu o filme com o Miguel e a Sílvia.

'Margarida saw the movie with Miguel and Sílvia.'

The choice given to subjects was between deciding that Miguel went to the movies alone or that he went to the movies with Margarida and Sílvia. Even though speakers interpret the test sentence, given its syntax, as meaning that Miguel went to the movies, one can actually pragmatically allow the additional inference that Miguel went to the movies with Margarida and Sílvia (since the context of the story indicated that they went to the mall together). ${ }^{12}$ In (13), the unexpected answer matching a non-obligatory control antecedent (13b) given by adults and 11-12-year-olds may be a case in which this pragmatic inference was taken into account. This type of answer corresponded to $20.6 \%$ of the answers by adults to the NINFL OC test items, and $17.9 \%$ of the answers by adolescents. 9 adolescents and 12 adults gave this type of unexpected answer to non-inflected infinitive items at least once. ${ }^{13}$

Strict/sloppy reading under ellipsis: Looking at the results from this condition (Fig. 5), we see that 6-7 and 9-10-year-olds appear to generalize a sloppy reading in both inflected and non-inflected infinitive items. This results in a low rate of strict readings with inflected infinitives and a high rate for the choice of sloppy reading with non-inflected infinitive items. An alternative way to interpret children's results in this condition would be to say that children want to reconstruct the closer subject in the ellipsis/omission site and this leads them to prefer a sloppy reading across the board-we will return to this issue in detail in section 6.

On the contrary, EP adults show better results with inflected infinitives (giving a higher number of answers corresponding to strict reading) than with non-inflected infinitive items. To understand this, we should further consider individual test items, as in (14) and (15) below.

Most answers by adults to inflected infinitive items (INFLIN STR) such as (14) were as expected, i.e. strict readings. However, adults did not perform in this type of items as perfectly as with inflected infinitive items in the non-obligatory control (INFLIN NOC) condition (presented in Fig. 4). We suggest that the lower rate of expected answers here arises if adults (and adolescents) allow an additional interpretation for the null material, allowing it to be treated not only as VP-ellipsis, but also as Null Complement Anaphora (NCA). That is, certain predicates selecting for a sentential complement can also select a pro complement (Null Complement Anaphora) that can refer to a discourse/pragmatic antecedent. Given this possibility especially in EP, the omitted complement in a test sentence such as in (14) would be structurally ambiguous between VP ellipsis and Null Complement Anaphora, if subjects allow the particular predicate to license NCA.

Story: O Miguel comprou uma televisão. O Miguel, o Ronaldo e a Margarida não tinham certeza de qual o melhor lugar para a televisão. O Miguel queria a TV na sala, mas não tinha muito espaço livre na sala para a televisão. Havia mais espaço na cozinha.

Miguel bought a TV. Miguel, Ronaldo and Margarida were not sure about the best place to put the TV. Miguel wanted the TV in the living room, but he did not have much free space there. There was more space in the kitchen.

\footnotetext{
11 There were only two test items for each of the conditions with non-inflected infinitives, since these conditions were used mostly as experimental controls.

${ }^{12}$ It is important to notice that in each one of stories it was necessary to have at least two participants, to allow the possibility of a plural antecedent in the test sentences with infinitive complements.

${ }^{13}$ In addition, subjects were given the option of choosing neither one of the proposed readings and instead giving their own reading/description, which was included in the count for the description it corresponded to (e.g. (13a,b)). However, in some cases subjects chose this option but gave an unclear alternative description, or one which did not match either the correct or the incorrect description provided for each test sentence. Answers like this were still counted with the incorrect description.
} 
Test sentence:

O Miguel achou mal colocarem a televisão na cozinha, mas o Ronaldo adorou _. the M. found bad put-INF-3PL the TV in.the kitchen but the R. loved 'Miguel didn't like putting the TV in the kitchen, but Ronaldo loved to.' Descriptions:

a. $\quad$ O Ronaldo colocou a televisão na cozinha juntamente com a Margarida. 'Ronaldo put the TV in the kitchen together with Margarida.' (expected)

b. O Ronaldo colocou a televisão na cozinha.

'Ronaldo put the TV in the kitchen.'

The VP ellipsis possibility implies projected structure which is not pronounced and has an interpretation determined by a parallel syntactic antecedent, which in the case of (14) leads to a strict reading interpretation; that is, Ronaldo loved the fact that they put the TV in the kitchen. The NCA interpretation gives rise to a complement pro that gets a freer interpretation from the discourse/situational context (see e.g. Santos, 2009a; cf. Cyrino and Matos, 2006 for discussion on the nature of NCA in EP and $\mathrm{BP})$; that is, Ronaldo could have loved putting the TV in the kitchen alone, or putting it there together with someone else. Given the latter possibility, subjects could choose the unexpected answer/description in (14), which matched the sloppy reading as a possibility. Despite both possibilities of inference from discourse, the results with inflected infinitives in this condition show that adults still prefer the strict reading, as expected, which means that they are sensitive to the strict reading condition on the inflected infinitive. This also means that adults prefer the parallel interpretation of the omitted material, i.e. the VP ellipsis interpretation. $^{14}$

Adults had a worse performance in items with non-inflected infinitives (NINFL SLOP) such as (15). Notice that in these cases the unexpected answer may be obtained very much in the same way as the unexpected reading in obligatory control (NINFL OC) items was obtained: by pragmatic inference (the fact that Margarida swam does not mean that she did it alone, she may have been swimming with Sílvia). ${ }^{15}$ In addition, the fact that an NCA interpretation is available also in these cases (in which the omitted material may get its interpretation from general discourse or pragmatic context) may have increased the rate of unexpected answers (see also fn. 14). We return to this in further detail in section 6 .

$$
\begin{aligned}
& \text { Story: O Miguel, a Margarida e a Sílvia foram para o clube de natação. Que pena que o Miguel não goste da piscina. } \\
& \text { Miguel, Margarida and Sílvia went to the pool. What a pity that Miguel doesn't like the swimming pool. } \\
& \text { A Sílvia disse depois o que aconteceu: } \\
& \text { Sílvia said what happened: } \\
& \text { Test sentence: } \\
& \text { O Miguel não gostou da ideia de nadar, mas a Margarida adorou. } \\
& \text { the Miguel not liked of.the idea of swim-INF but the Margarida loved. } \\
& \text { 'Miguel disliked swimming, but Margarida loved to.' } \\
& \text { Descriptions: } \\
& \text { a. A Margarida nadou na piscina, e a Sílvia também. } \\
& \quad \text { Margarida swam in the pool and Sílvia too.' } \\
& \text { A. Margarida nadou na piscina. (expected) } \\
& \text { 'Margarida swam in the pool.' }
\end{aligned}
$$$$
\text { Miguel, Margarida and Sílvia went to the pool. What a pity that Miguel doesn't like the swimming pool. }
$$

Split/non-split antecedents: Looking at Fig. 6, it seems that there are generally better results with inflected infinitives than with uninflected infinitives, regarding the hypothesized contrast between split antecedents with inflected infinitives and non-split antecedents with non-inflected infinitives. A more detailed analysis of these results is very revealing.

First, the results with inflected infinitives are actually better than they look like on average. The split-antecedent reading was syntactically the only possibility with the test items presenting 3rd plural inflected infinitives, as in the test item (16), in which both Miguel and Ronaldo would have to clean the garden to provide a correct interpretation for the embedded inflected infinitive. However, the split-antecedent reading was only one of two possible interpretations licensed by the syntactic structure for the 1 st plural inflected infinitives, as in the test item (17).

\footnotetext{
14 As we mentioned in fn. 13, although subjects had the possibility of choosing neither one of the proposed readings and giving their own reading / description, they sometimes took that option and gave an unclear alternative description. The strict / sloppy condition was the condition in which adults more often gave this type of answer (they are residual in other conditions): $21 \%$ with non-inflected infinitives and $12.6 \%$ with inflected infinitives, in the strict / sloppy condition. This is compatible with a scenario in which adults would consider the sentences in the strict / sloppy condition, especially with non-inflected infinitives, as potentially ambiguous.

${ }_{15}$ The possibility of pragmatic inferences, which may be easier in certain contexts, is compatible with the fact that there was an item effect: adults and adolescents chose the unexpected answer around $50 \%$ of the time with the test item in (15) but only about $20 \%$ of the times in the case of the other test item with non-inflected infinitives in this condition. Both test items had the same stranded predicate: adorar 'love'.
} 
O Miguel convenceu o Ronaldo a limparem o jardim.

the Miguel convinced the Ronaldo to clean-INF-3PL the garden

'Miguel convinced Ronaldo that they (should) clean the garden.'

P1: shows Ronaldo alone, cleaning the garden. (while Miguel watches from the window)

P2: shows Miguel and Ronaldo cleaning the garden (no one else is in either one of the pictures) (expected)

\author{
O Carlos disse: $\mathrm{O}$ Ronaldo disse-me a mim e ao Miguel para pescarmos. \\ the Carlos said: The Ronaldo told-me to me and to-the Miguel to fish-INF-1PL. \\ 'Carlos said: Ronaldo told Miguel and me that we (should) fish.'
}

In (16), if subjects are sensitive to the 3rd pl inflection, they understand that Ronaldo alone cannot be the antecedent of the subject of the inflected infinitive; on the contrary, in (17) the indirect object of the matrix verb alone (i.e. Carlos and Miguel) can satisfy the requirement of a 1st plural antecedent for the pro in the subject position of the inflected infinitive, although the split-antecedent reading including Carlos as the antecedent is also possible.

Indeed, all the age groups favored a split-antecedent interpretation for the 3rd plural inflected infinitive test items, which were compatible only with this interpretation. In 3rd person plural contexts, adults and adolescents are at ceiling in the choice of split antecedents (there was only one unexpected answer, by an adolescent); 9-10-year-olds give 85\% correct answers; 6-7-year-olds give 82\% correct answers. The results are therefore a lot better than the averaged results in Fig. 6 might otherwise indicate.

The apparently unexpected results obtained with uninflected infinitives (NINFL NO-SPL) can again be explained if pragmatic inferences are taken into account. Considering a test case such as (18), this means that even though the relevant non-split antecedent reading is determined by the syntax (Miguel and Carlos rode a horse, description (18a)), it may be inferred that Ronaldo also rode a horse. Given the context, the latter interpretation is pragmatically available, and it was indeed allowed in this type of test item by more than $50 \%$ of each subject group (17 adults, 25 adolescents, 15 9-10-year-olds and 15 6-7-year-olds), leading them to pick a description in this case that was equivalent to a split antecedent interpretation (18b), but partially resulting from a pragmatic inference.

Story: O Ronaldo, o Miguel e o Carlos foram para uma quinta onde há cavalos.

'Ronaldo, Miguel and Carlos went to a farm where there were horses.'

Test sentence:

O Miguel disse: $\mathrm{O}$ Ronaldo convenceu-me a mim e ao Carlos a andar a cavalo.

The Miguel said: the $\mathrm{R} \quad$ convinced me to me and to-the $\mathrm{C}$ to ride-INF on horse

'Miguel said: Ronaldo convinced Carlos and me to ride a horse.'

Description choices:

a. O Carlos andou de cavalo, e o Miguel também.

'Carlos rode a horse, and Miguel did too.'

b. O Carlos andou de cavalo, e o Miguel e o Ronaldo também.'

'Carlos rode a horse, and Miguel and Ronaldo did too.'

The relevance of the overall results presented above is discussed in the next section.

\title{
6. Discussion
}

\subsection{EP children vs. EP adolescents and adults: similarities and differences}

The results reported above show both differences and similarities between children and adolescents or adults. What do these results reveal in general concerning different groups' knowledge of inflected infinitives?

The MRT task tested knowledge of morphological properties of inflected infinitives as well as pure syntactic properties, i.e. distributional properties. MRT results reveal that EP subjects of age 9-10 and older in general have knowledge of inflected infinitives. As we have seen before, the unexpected answers in the adult and the 9-10-year-old groups are mostly due to the overacceptance of inflected infinitives selected by predicates that are not expected to admit an inflected infinitive in their complement (see section 3 and below). In the case of 6-7-year-olds, the MRT task was generally difficult for some children. However, as we have seen, 10 of these subjects showed performance above chance and, if we look at the pattern of unexpected answers, the highest rates of unexpected answers are obtained with the same test items that caused difficulties for older children and adults. Therefore, we conclude that at least some 6-7-year-olds already have substantial knowledge of inflected infinitives. The fact that this knowledge includes partial deviations from what would be expected as an adult norm will be further discussed in section 6.2 . 
Now, how do the MRT results compare with the IMT results? Recall that the IMT task aimed at assessing the syntax/ semantics interface in the interpretation of inflected infinitives. First, children from both age groups (6-7 and 9-10-yearolds) differ from the older groups in that they give more expected answers mapping to obligatory control for test items with non-inflected infinitives, presumably because children appealed less often to additional pragmatic inferences than adults and adolescents did. The fact that children make less (or less frequent) pragmatic inferences than adults is indeed in agreement with previous literature, such as Noveck (2001) and Papafragou and Musolino (2003). This means that, in certain contexts, children may rely less on pragmatic knowledge to determine their interpretations. However, we do not intend to argue that children's pragmatic (and discourse) knowledge is somehow impaired or delayed, something that several researchers have already argued against (see De Cat, 2002; Unsworth, 2005; Santos, 2009a). It may only be the case that in certain instances, given two possible options, children less frequently rely on pragmatic inferences possibly due to properties of the task at hand. ${ }^{16}$

In addition, considering the IMT control condition, we have seen that some 6-7-year-olds differ from the other groups in that they choose obligatory control readings (requirement of a local c-commanding antecedent) also for the subject of inflected infinitives. This fact may be understood in one of two ways: (i) either 6-7-year-old children are taking the inflected infinitive as a non-inflected infinitive and are completely ignoring the inflection-in this case, they would be assuming that the subject of the inflected infinitive is a PRO or (if the movement theory of control is accepted, see e.g. Hornstein, 2003; Pires, 2006) a DP moved to the subject position in the higher clause; (ii) or these children are assuming that the pro in the subject position of an inflected infinitive should be taken as co-referent with an antecedent in the matrix clause. The idea that pro subjects in embedded clauses are preferably interpreted as co-referent with a possible antecedent in the matrix clause is in agreement with the idea that in null subject languages pro and lexical pronouns do not have the same distribution and the same interpretations (see Montalbetti, 1984). In fact, in finite complement clauses such as (19), the preferred interpretation for the pro subject is the interpretation that takes it to be co-referent with the matrix subject.

\section{A Teresa $_{\mathrm{i}}$ acha que pro $\mathrm{i} / \mathrm{k}$ vai ao cinema.}

'Teresa thinks that (she) goes to the movies.'

This co-reference choice has also been observed for null subjects of subjunctive complements in Spanish and in Greek, for both children and adults (Goodluck et al., 2001, cf. Kapetangianni, 2010). However, in different cases the discourse context may actually determine a disjoint interpretation between the embedded pro and the most local antecedent. Lobo (in press:17) argues that although there is a general preference for pro in an embedded clause to be co-referent with a salient local antecedent in the matrix clause, the chosen reading is determined on the basis of the discourse and pragmatic context, as in (20), in which the reference of pro is 'the parents', which are not the most local antecedent. ${ }^{17}$

$$
\begin{aligned}
& \text { Ninguém sabe o que os pais } s_{k} \text { vão fazer. Os miúdos acham que pro } k \text { vão ao cinema. } \\
& \text { 'No one knows what the parents }{ }_{k} \text { will do. The children think that (they }{ }_{k} \text { ) will go to the movies.' }
\end{aligned}
$$

The difference in the case of some EP 6-7-year-olds we tested is that, in order to obtain the relevant co-referent reading for pro, they would need to ignore the plural inflection in the inflected infinitive. The fact that these 6-7-year-olds may not always choose the expected disjoint (non-obligatory control) interpretation for null subject pro of inflected infinitives suggests that they have a stronger preference for searching a salient antecedent for pro in the matrix clause, in such a way that leads them to sometimes override inflection.

Alternatively, we could attempt to account for the co-reference preference shown by some EP 6-7-year-olds in a different way: they do not need the null subject of the inflected infinitive to be controlled by a DP in the matrix clause, but they prefer that this null subject include the referent of a salient DP in the matrix clause-we will call this the "inclusive reading". However, our test results actually allow us to discard an inclusive reading approach in favour of a "salient antecedent"/ obligatory control approach to explain the co-referent choice made by some of these children for inflected infinitives. There were two types of test items in the control/local c-commanding antecedent condition, as in (21) and as in (22). In the case of (21), the expected adult answer would not be inclusive of the matrix subject; in (22) the adult answer would include the matrix subject.

$$
\begin{aligned}
& \text { O Mickey ficou satisfeito por lavarem o carro. } \\
& \text { Mickey was happy for wash-INF-3PL the car } \\
& \text { P1: shows Mickey washing the car alone (no one else is on the picture). } \\
& \text { P2: shows Donald and Daisy washing the car (Mickey is not on the picture). (expected) }
\end{aligned}
$$

\footnotetext{
${ }^{16}$ In other instances, as we saw regarding the discussion of example (18) above, children's unexpected answers to non-inflected infinitive items in the split antecedent condition may indeed have partially resulted from pragmatic inferences.

17 Kapetangianni (2010) showed experimentally that the relevant discourse context can also favor a disjoint interpretation for null subjects of subjunctives in Greek.
} 


\author{
O Donald ficou satisfeito por vermos televisão. \\ Donald was happy for watch-INF-1PL television \\ P1: shows Donald alone, watching TV. \\ P2: shows Donald, Mickey and Daisy watching TV. (expected)
}

If children's preference were specifically for an inclusive reading, we should expect worse results in items of type (21) than in items of type (22). This is not what happened. Looking at 6-7-year-olds' results by item, we see that children gave $35.4 \%$ wrong (unexpected) answers to items of type (21) and $54.1 \%$ wrong answers to items of type (22). Given this, we should consider the possibility that the children that incorrectly picked picture (P1), which represents the co-referent reading, interpreted the subject of the inflected infinitive as controlled.

Let us consider now how the results of the OC/NOC condition correlate with the results obtained in the two other IMT conditions. In particular, how does this correlate with what we called a strong preference by 6-9-year-old children for sloppy readings in the strict/sloppy reading condition? We saw that adults and adolescents seem aware of the different interpretative possibilities available in EP for the null complement in a sentence such as (14), repeated below as (23). In case the sentence can be interpreted as involving either VP ellipsis or Null Complement Anaphora, subjects have more available interpretations and this justifies the partially varying choices of adults and adolescents in this condition (although as we pointed out adults as a group still give significant preference to a strict reading in the case of inflected infinitives).

$$
\begin{aligned}
& \text { O Miguel achou mal colocarem a televisão na cozinha, mas o Ronaldo adorou _. } \\
& \text { The M found bad put-INF-3PL the TV in.the kitchen, but the R loved_- } \\
& \text { 'Miguel found it bad to put the TV in the kitchen, but Ronaldo liked.' }
\end{aligned}
$$

However, we noted that (6-7 and 9-10-year-old) children in general prefer sloppy readings both with inflected and with non-inflected infinitives. What we called a sloppy reading in these contexts, following Pires (2006), is in fact a reading in which the null subject position in the omitted complement clause is co-referent with the subject in the local matrix clause (in the case of the sentence in (23), Ronaldo). This means that the preference for a sloppy reading in this condition may indeed have an explanation similar to the one we proposed for children's incorrect choice of the control readings in the OC/NOC condition. The only difference in this case is that the sloppy reading is possible according to the adult grammar as well, due to the possibility of freer readings resulting from Null Complement Anaphora. This may in fact explain why 9-10-year-olds also show a general preference for sloppy reading in the strict/sloppy reading condition, even though overall they perform in an adult manner in the OC/NOC condition: 9-10-year-olds as a group have knowledge of the OC/NOC distinction for (non-) inflected infinitives in the adult grammar and preclude an obligatory control (OC) reading of a sentence such as (21) above, a case in which they would have to ignore inflection in order to maintain the OC reading; however, they prefer what appears to be a controlled reading in the strict/sloppy condition, by choosing the sloppy reading overall. ${ }^{18}$

In general we seem to be detecting a preference for co-referent interpretation of null subject pro among younger speakers, and not an inability to recognize inflected infinitives, particularly their morpho-syntactic properties.

Turning now to the split/non-split condition, we have seen that, when children interpret test items in the split/non-split condition, such as (16) repeated as (24) below, they show that they are aware of the inflection in the embedded infinitive and they know that the object DP that could function as a potential controller in the syntax in fact cannot satisfy alone the number requirements of the subject of the inflected infinitive. As a result, 9-10-year-olds give $85 \%$ correct split-antecedent answers to this type of items and, crucially, 6-7-year-olds give $82 \%$ correct answers in the same cases.

$$
\begin{gathered}
\text { O Miguel convenceu o Ronaldo a limparem o jardim. } \\
\text { Miguel convinced Ronaldo to clean-INF-3PL the garden }
\end{gathered}
$$

P1: shows Ronaldo alone, cleaning the garden. (while Miguel watches from the window)

P2: shows Miguel and Ronaldo cleaning the garden (no one else is in either one of the pictures) (expected)

\footnotetext{
${ }^{18}$ A general availability of the sloppy reading across age groups may be a plausible explanation to account for the higher rate among 6-7-year-olds of answers choosing the sloppy reading for inflected infinitive items in the strict/sloppy condition than the OC reading in the OC/NOC condition: some 6-7year-olds that give an NOC reading to subjects of inflected infinitives in the first condition still prefer a control / sloppy reading in general in the strict / sloppy condition.

A remaining question is why only adults override this availability of the sloppy reading by showing a preference for the expected strict reading in the case of inflected infinitives. First, as we have seen, the items with non-inflected infinitives may favor additional readings that are available by pure pragmatic inference, the same way as we considered in the OC condition. Nevertheless, the fact that strict readings are still preferred (by adults) with inflected infinitives may suggest a general preference for a parallel antecedent over different possibilities given by a Null Complement Anaphora interpretation (a case of deep anaphora in the perspective of Hankamer and Sag, 1976). Santos (2009b) shows that young EP speakers (4-6-year-olds) do constrain their reading of VP ellipsis contexts in an adult-like way, by preferring parallel readings of VP ellipsis. In English, Duffield and Matsuo (2009) report that English native speakers not only show a clear effect of parallelism in the interpretation of VP ellipsis but also show a weaker effect of parallelism in the interpretation of VP anaphora (do it), an overt case of deep anaphora. Matsuo and Duffield (2001) suggest that children distinguish (therefore, are aware) of both surface (ellipsis) and deep anaphora. However, further research is necessary regarding these issues; to our knowledge there is no work comparing the acquisition of VP-ellipsis and Null Complement Anaphora in EP.
} 
On the contrary, when interpreting items such as (17), repeated as (25), in which the item in the object position alone satisfies the number requirements of the inflected infinitive, the level of split-antecedent readings lowers significantly: 6-7year-olds give $56.25 \%$ split-antecedent answers (P2) and 9-10-year-olds do the same in 45\% of their answers.

O Carlos disse:
O Ronaldo disse-me a mim e ao Miguel para pescarmos.
Carlos said:

P1: shows Carlos and Miguel alone, fishing.

P2: shows all three fishing (expected).

These results clearly show that children (even 6-7-year-olds) are sensitive to the morpho-syntax of inflected infinitives and its effects on determining syntactic-semantic properties of non-obligatory control, including the possibility of splitantecedents. Now why do children clearly show this sensitivity to inflection more in the split/non-split condition and not in the other conditions?

To answer this question, we point out one difference between this condition and the other two. In this condition, both the split and the non-split reading allowed the antecedent for the subject of the inflected infinitive to be found in the matrix clause (and not in the broader discourse context provided by the test story). This may more easily satisfy children's preference for a co-referent antecedent for null subject pro when interpreting the subject of the inflected infinitive in EP. This is not unexpected, since we have referred to work indicating that this is the preferred reading of pro subjects, even if it does not apply in all contexts. Notice that this is different from the "inclusive reading" which we considered and excluded as a possibility before: in the "inclusive reading" the potential controller must be included in the antecedent of the inflected infinitive subject but not all the entities understood as the reference of the subject need be referred in the antecedent clause; in split antecedent sentences, all the entities that may function as an antecedent of the subject are referred in the matrix clause.

In addition, the split/non-split condition reveals that children are probably aware of the subject/object control nature of the matrix predicate. Split antecedent test items involved predicates in the matrix clause that could also allow object control (specifically with non-inflected infinitives). If children always wanted the subject in the matrix clause to be included in the reference of the inflected infinitive, similar to a subject control reading, they would also prefer split readings of sentences such as (25), contrary to fact.

These results indicate that children are sensitive to the morpho-syntactic properties and at least part of the semantic properties of inflected infinitives at a point in which they may not yet show completely adult-like use of certain discourse or pragmatic interface conditions on the interpretation of the subjects of inflected and non-inflected infinitives. Still, there are different aspects of the results and analysis presented here, especially regarding the strict vs. sloppy reading condition and its interaction with VP ellipsis and Null Complement Anaphora interpretation that will certainly benefit from further research.

\subsection{EP children and adolescents vs. BP children and adolescents}

One of the initial goals of this project was to obtain independent results regarding child L1 acquisition of the morphosyntactic and syntax-semantic properties of inflected infinitives in a language that provides robust evidence in the child PLD for the acquisition of these properties, as is the case of EP. In addition, given that the tests proposed here are equivalent to the tests carried out in Pires and Rothman (2009a), the results of both studies can be directly compared so that we can draw additional conclusions regarding the interdisciplinary interfaces between linguistic theory, language acquisition and language change, which were an important focus in the context of the acquisition of inflected infinitives in BP in Pires and Rothman (2009a, 2010).

Pires and Rothman (2009a, 2010) tested BP children and teenagers from upper-middle class background, between the ages of 6 and 15. They used the Morphological Recognition Task (MRT) and an Interpretation Matching Task (IMT) that were later modified for dialect and employed in the present EP study. The results of the MRT indicated that all the age groups were able to identify the correct properties of finite indicative clauses and of uninflected infinitives, and to correct inappropriate uses of these forms. Nevertheless, only the 13-15-year-old BP group was fully competent at identifying both correct and incorrect uses of inflected infinitive morphology, both in 1PL and 3PL forms. Moreover, even though the groups up to age 12 performed poorly regarding inflected infinitives, the fact that they were successful regarding their knowledge of other forms' properties (indicatives and uninflected infinitives) indicated that their difficulty with inflected infinitives was not the result of a general difficulty of the groups up to age 12 with this task, since they performed successfully regarding other verbal forms.

Crucially, the poor performance of the BP children/teenagers up to age 12 with the MRT regarding inflected infinitives is not matched by the current results from EP children/teenagers. As discussed in section 5, the EP MRT results provide evidence that at least half of the EP 6-7-year-old subjects and the majority of the 9-10-year-old subjects have knowledge of the morpho-syntactic properties of inflected infinitives. First, 11-12 EP teenagers showed performance in the MRT that was across-the-board equivalent to the adults, with no significant differences. The 9-10-year-old also did not show any significant difference from the teenagers (and, as a consequence, performance also equivalent to the adult's) except in the case of the 1PL inflected infinitive forms that required correction, for reasons that may have involved the overacceptance of 
individual forms, as discussed in section 5. Moreover, there was a subset of the 6-7-year-old group that actually performed above chance across the board. In sum, these results indicate overall that the EP children and teenagers from the earliest tested age (6-years-old) show evidence of partial or complete proficiency regarding the properties of inflected infinitives. Such evidence is in sharp contrast with the BP children/teenagers, who only start showing partial knowledge of the morphosyntax of inflected infinitives at the ages 10-12.

This contrast lends independent support to the proposal made in Pires and Rothman (2009a, 2010) that BP children/ teenagers fail to acquire the properties of inflected infinitives early because these properties are no longer robustly instantiated in their colloquial dialects. The fact that BP speakers still learn these properties at a later age results from later substantial exposure of these speakers (e.g. through schooling and/or increased literacy) to the standard dialect in which inflected infinitives are still productive. However, since colloquial EP dialects provide robust input with inflected infinitives, EP children manage to acquire the properties of these forms earlier through native acquisition.

This so far unnoticed distinction in the acquisition of the two dialects stems from a complex and ongoing scenario of language change that affected only the properties of infinitives in BP, and not (yet or in the same way) in EP (see Pires, 2006, Pires and Rothman, 2009a,b; Rothman, 2007). Whereas BP has undergone grammatical changes that have for the most part eliminated inflected infinitives from colloquial dialects, it is interesting to point out that our results also provide some evidence of a possible change in course in colloquial EP, which might be taking EP in a direction that is the opposite of the retracting trend seen in BP regarding the reduced availability of inflected infinitives. As pointed out in previous sections, our EP MRT indicated an overacceptance by at least one-third of the adults of inflected infinitives in the complement of volitional verbs, as in (26), which is expected to be ungrammatical in EP. This indicates a potential source of dialectal variation in EP that may result from an ongoing reverse process of grammatical change by which inflected infinitives may be extending in EP to contexts previously taken to allow only uninflected infinitives, differently from the path observed in BP. ${ }^{19}$ Interestingly, a similar pattern of overacceptance was clear at least among the 9-10-year-old group, also in the complement of other verbs (see section 5.2 ).

\section{*O Paulo e o Geraldo querem irem buscar as canas de pesca.}

Paulo and Geraldo want go-INF-3PL get-INF the fishing rods.

We turn now to a comparison between BP and EP acquisition regarding the Interpretation Matching Task (CMT in Pires and Rothman, 2009a). Whereas all the BP groups tested by Pires and Rothman (2009a, 2010) did very well with properties of obligatory control relating to non-inflected infinitives, only the 13-15-year-old and 10-12-year-old groups perform in a target-like manner regarding the properties of non-obligatory control in inflected infinitives. Both the 6-7 and 8-9-year-old BP groups tested by Pires and Rothman showed significant differences in their ability to assign the expected interpretation to all three non-obligatory control properties of inflected infinitives (compared to the 13-15-year-old groups). Although a direct comparison to the EP IMT results is less straightforward due to a higher rate of non-expected answers across different groups in EP, including the adults, it is possible to see that in the IMT there is also a clear contrast between BP and EP. EP 9year-olds perform without any significant difference from adults in the inflected infinitive non-obligatory control, and were very close to adults in the split antecedent conditions, especially regarding the cases that required obligatory split antecedents (24), performing at $85 \%$. As we discussed, even among the 6-7-year-olds there is a subset (10) that performs above chance ( 6 of them at ceiling) in the non-obligatory control condition. In the split antecedent condition, considering in particular the test cases that required obligatory split antecedents, 6-7-year-old showed $82 \%$ of correct responses, clearly above chance. These results clearly contrast with the BP 6-9-year-olds in Pires and Rothman (2009a), in that they in fact behaved at or below chance regarding all three IMT properties of inflected infinitives, indicating that BP children acquire theses properties later than EP children. This again provides support for the view that, contrary to EP speakers in general, educated, middle-class BP children/teenagers acquire the properties of inflected infinitives much later, only as the result of their exposure to the standard dialect of BP, primarily through explicit learning in school and through more exposure to reading and hearing that dialect.

Before we conclude, it is relevant to further discuss why the EP teenagers and adults seem to perform worse than BP children at the matching age, regarding the strict ellipsis interpretation of inflected infinitives, which should not be expected if EP speakers should in general acquire the properties of inflected infinitives earlier than BP speakers. As we argued in section 6.1, a substantial part of the difficulty that the EP subjects (especially from age 11 to 12 on) experienced with the strict vs. sloppy reading interpretation is not the result of an intrinsic difficulty in their ability to acquire this distinction in EP, but rather the results of interpretive choices that may be favored by EP speakers but not by BP speakers, as can be seen by what appears to be distinct target competence between EP and BP. The latter is supported by the fact that the oldest BP group (13-15-year-olds) performs at ceiling regarding the choice of the strict reading of inflected infinitives, better even than the EP adults, who overall perform only slightly better than 0.7 . Similarly, whereas the BP $10-12$-year-olds show no significant

\footnotetext{
${ }^{19}$ According to Ana Maria Martins (p.c. 2010), it seems that no one has ever looked at the occurrence of inflected infinitives in dialectal corpora of Modern EP, such as Cordial-SIN. However, Martins has also observed a similar overgeneralization of the use of EP inflected infinitives in everyday speech (see Martins, in press, end of section 5). According to Martins, these non-standard forms of inflected infinitives may be generated as a result of the same type of syntactic ambiguity that gave rise to inflected infinitives in ECM contexts, i.e. syntactic ambiguity in coordination and gapping contexts.
} 
difference from the 13-15-year olds regarding this choice (although they show individual variation), the EP 11-12-year-olds perform at or below chance regarding their choice of strict reading for inflected infinitives.

Our suggestion was that EP adults admit unexpected readings in both inflected and non-inflected infinitives due to the ability of at least a subset of adults to interpret null material as Null Complement Anaphora. In addition, this possibility should be rather restricted in the case of inflected infinitives in Standard BP, as attested by the fact that the groups showing target performance (13-15-year-olds) perform at ceiling, by choosing the strict reading interpretation of inflected infinitives $95 \%$ of the times, indicating that a Null Complement Anaphora interpretation is not a possibility here. ${ }^{20}$ This indicates that, despite the restricted nature of inflected infinitives in BP, arguably resulting from late exposure to standard BP, they may impose specific restrictions that are not identical to the ones found in EP. We leave for future research further investigation regarding the availability and analysis of Null Complement Anaphora in both languages.

\section{Conclusion}

This paper investigated aspects of the morpho-syntactic, syntax-semantics and syntax-pragmatics interfaces involved in the acquisition of infinitives in dialects of Portuguese. The results of the experiments we presented here provided the first results to date regarding the acquisition of inflected vs. non-inflected infinitives in EP, also in comparison with BP. It is shown here that, despite the complexity of the tasks involved and the existence of certain pragmatic options in the interpretation of inflected and non-inflected infinitives, the youngest EP children that were able to participate in the tests successfully (6-7year-olds) showed evidence of knowledge of the morpho-syntactic properties and at least some syntax-semantic properties of inflected infinitives. These results contrast with the results of comparable experiments in Pires and Rothman (2009a, 2010), which show that BP speakers acquire inflected infinitives much later, reaching competence only at the age 13-15. This difference of outcome provides independent support for the argument that the contrast between inflected and uninflected infinitives is not an intrinsically late-acquired phenomenon, but its delayed acquisition in BP is indeed due to its limited availability or absence from the PLD for the acquisition of colloquial dialects of BP, as the result of previous or ongoing language change.

On the other hand, the results obtained with EP speakers showed that children may acquire the morpho-syntactic properties of inflected infinitives before they attain complete adult knowledge of their interpretative properties. In particular, we have suggested that different preferences in the interpretation of pro subjects of inflected infinitives (namely, the need to find an antecedent for pro in the previous discourse) can also affect children's interpretation of sentences with inflected infinitives.

\section{Acknowledgments}

We would like to thank various colleagues for helpful comments on aspects of this project design or help in the data collection and analysis, especially: Silvana Abalada, Pilar Barbosa, Madalena Colaço, João Costa, Inês Duarte, André Eliseu, Cristina Flores, Elena Gavruseva, Ângela Fernandes, Mary Kato, David Lightfoot, Michael Iverson, Ana Maria Martins, Robin Queen and Carlos Quicoli. We would also like to thank the entire staff at the ACBEU in Salvador, Brazil, but especially Clara Ramos, as well as Agrupamento de Escolas Mães d'Água, Amadora and Centro de Linguística da Universidade de Lisboa for assistance in the collection of data in Brazil and Portugal. Different data sets addressed in this paper have been presented at GALANA 2008, LSA 2009, LSRL 2008, Romance Turn 3, and GALA 2009. We thank the audience at these meetings for thoughtful questions and suggestions. Any remaining errors are entirely our own.

\section{References}

Akmajian, A., 1984. Sentence types and the form-function fit. Natural Language and Linguistic Theory 2, 1-23.

Ambar, M., 1989. Para uma Sintaxe da Inversão Sujeito-Verbo em Português. PhD dissertation. Universidade de Lisboa.

Chomsky, N., 1995. The Minimalist Program. MIT Press, Cambridge.

Chomsky, N., 2005. Three factors in language design. Linguistic Inquiry 36, 1-22.

Cyrino, S.M.L., 1997. O Objeto Nulo no Português do Brasil: Um Estudo Sintático-diacrônico. (The null object in Brazilian Portuguese: a syntactic-diachronic study). Editora UEL, Londrina.

Cyrino, S.M.L., 2004. On the existence of null complement anaphora in Brazilian Portuguese. Revista Letras 63, 97-117.

Cyrino, S.M.L., Matos, G., 2006. Null complement anaphora in Romance: deep or surface anaphora? In: Doetjes, J., Gonzalez, P. (Eds.), Romance Languages and Linguistic Theory 2004. John Benjamins, Amsterdam/Philadelphia.

De Cat, C., 2002. French Dislocation. PhD. Dissertation. University of York.

Duffield, N., Matsuo, A., 2009. Native speaker's versus L2 learners' sensitivity to parallelism in VP ellipsis. Studies in Second Language Acquisition 31, 93123.

Figueiredo Silva, M.C. 1996. A Posicão do Sujeito no Português Brasileiro. (The Subject Position in Brazilian Portuguese). Editora da Unicamp, Campinas. Goodluck, H., Terzi, A., Diaz, G.C., 2001. The acquisition of control crosslinguistically: structural and lexical factors in learning to license PRO. Journal of Child Language $28,153-172$.

Grohmann, K., Etxepare, R., 2003. Root infinitives: a comparative view, Probus 15.2, 201-236.

Hankamer, J., Sag, I., 1976. Deep and surface anaphora. Linguistic Inquiry 7.3, 391-426.

Hornstein, N., 2003. On control. In: Hendrick, R. (Ed.), Minimalist Syntax. Blackwell, Malden, MA, pp. 6-81.

Jackendoff, R., 2002. Foundations of Language: Brain, Meaning, Grammar, Evolution. Oxford University Press, Oxford.

\footnotetext{
${ }^{20}$ Cyrino (2004) indeed argues that an interpretation of what may be Null Complement Anaphora contexts in BP is close to the interpretation given to VP ellipsis. Santos (2009a) argues for the existence of Null Complement Anaphora derived as pro in EP. But see also the discussion in Cyrino and Matos (2006).
} 
Kapetangianni, K., 2010. The Minimalist Syntax of Control in Greek. Ph.D. dissertation. University of Michigan, Ann Arbor.

Kato, M.A., 2005. Gramática do letrado: Questo?es para a Teoria Gramatical.(Grammar of the Literate: Questions for Grammatical Theory). In: Marques, M. A., Koller, E., Teixeira, J., Lemos, A.S. (Eds.), Ciências da linguagem: Trinta Anos de Investigação e Ensino. CEHUM, Braga, pp. $131-145$.

Kato, M.A., Cyrino, S.M.L., Corrêa, V.R., 2009. Brazilian Portuguese and the recovery of Lost Clitics through schooling. In: Pires, A., Rothman, J. (Eds.), Minimalist Inquiries into Child and Adult Language Acquisition: Case Studies Across Portuguese. Mouton DeGruyter, Berlin/New York, pp. 245-272.

Koike, D., 1983. The inflected infinitive in colloquial Brazilian Portuguese as a marker of social dialects. In: Bergen, J.J., Garland, D.B. (Eds.), Spanish and Portuguese in Social Context. Georgetown University Press, Washington, DC, pp. 92-104.

Lightfoot, D., 1991. How to Set Parameters: Arguments from Language Change. MIT Press, Cambridge, MA.

Lobo, M., in press. O Sujeito nulo: sintaxe e interpretação. In: Bacelar do Nascimento, M,F., Mota, M.A., Cruz, L.S., Raposo, E., Viana, M.C. (Eds.), Gramática do Português. Lisbon: Centro de Linguística da Universidade de Lisboa/Fundação Calouste Gulbenkian.

Madeira, A.M., 1994. On the Portuguese inflected infinitive. In: Borgato, G. (Ed.), Teoria del linguaggio e analisi linguistica: XX Incontro di Grammatica Generativa. Unipress, Pádua, pp. 289-314.

Martins, A.M., 2001. On the origin of the Portuguese inflected infinitive: a new perspective on an enduring debate. In: Brinton, L.J. (Ed.), Historical Linguistics 1999: Selected Papers from the 14th International Conference on Historical Linguistics, Vancouver, 9-13 August 1999. John Benjamins, Amsterdam/ Philadelphia, pp. 207-222.

Martins, A.M., in press. Coordination, gapping, and the Portuguese inflected infinitive: the role of structural ambiguity in linguistic change. In: Jonas, D. (Ed.), Selected Papers from DIGS 8-Diachronic Generative Syntax Conference. New York: Oxford University Press.

Matsuo, A., Duffield, N., 2001. VP-ellipsis and anaphora in child language acquisition. Language Acquisition 9.4, $301-327$.

Montalbetti, M., 1984. Binding: On the interpretation of pronouns. Ph.D. dissertation, MIT.

Noveck, I.A., 2001. When children are more logical than adults: experimental investigations of scalar implicature. Cognition $78,165-188$.

Papafragou, A., Musolino, J., 2003. Scalar implicatures: experiments at the semantics-pragmatics interface. Cognition 86, $253-282$.

Pires, A., 2002. Cue based change: inflection and subjects in the history of Portuguese infinitives. In: Lightfoot, D. (Ed.), Syntactic Effects of Morphological Change. Oxford University Press, Oxford, pp. 142-159.

Pires, A., 2006. The Minimalist Syntax of Defective Domains: Gerunds and Infinitives. John Benjamins, Amsterdam.

Pires, A., Rothman, J., 2009a. Acquisition of Brazilian Portuguese in late childhood: implications for syntactic theory and language change. In: Pires, A., Rothman, J. (Eds.), Minimalist Inquiries into Child and Adult Language Acquisition: Case Studies Across Portuguese. Mouton de Gruyter, Berlin, pp. 129154.

Pires, A., Rothman, J., 2009b. Disentangling sources of incomplete acquisition: an explanation for competence divergence across Heritage Grammars. International Journal of Bilingualism 13.2, 211-238.

Pires, A., Rothman, J., 2010. Building bridges: evaluating syntactic change on the basis of experimental L1 acquisition. In: Domínguez, L., Guijarro-Fuentes, P. (Eds.), Selected Proceedings from Romance Turn III. Cambridge Scholars Press, Cambridge, pp. 357-385.

Quicoli, A.C., 1996. Inflection and parametric variation: Portuguese vs. Spanish. In: Freidin, R. (Ed.), Current Issues in Comparative Grammar. Kluwer, Dordrecht, pp. 46-80.

Raposo, E., 1987. Case theory and Infl-to-Comp: the inflected infinitive in European Portuguese. Linguistic Inquiry 18, 85-109.

Reinhart, T., 2006. Interface Strategies: Optimal and Costly Operations. MIT Press, Cambridge.

Roberts, I., Kato, M.A., 1993. Português Brasileiro: Uma Viagem Diacrônica. Homenagem a Fernando Tarallo. (Brazilian Portuguese: A Diachronic Journey. In Honor of Fernando Tarallo).Editora da Unicamp, Campinas.

Rodrigues, C., 2004. Weak morphology and A-movement out of Case Domains. Ph.D. dissertation, University of Maryland, College Park

Rothman, J., 2007. Heritage speaker competence differences. language change and input type: inflected infinitives in Heritage Brazilian Portuguese. International Journal of Bilingualism 11.4, 359-389.

Rothman, J., 2009. Knowledge of A/A'-dependencies on subject extraction with two types of infinitives in non-native Portuguese Adult Bilingualism. International Journal of Bilingualism 13.1, 111-140.

Rothman, J., Iverson, M., 2007. To inflect or not to inflect is the question indeed: infinitives in non-native Portuguese. Journal of Portuguese Linguistics 6.2, 530.

Santos, A.L., 2009a. Minimal Answers: Ellipsis, Syntax and Discourse in the Acquisition of European Portuguese. John Benjamins, Amsterdam/Philadelphia.

Santos, A.L., 2009b. Early VP ellipsis: production and comprehension evidence. In: Pires, A., Rothman, J. (Eds.), Minimalist Inquiries into Child and Adult Language Acquisition: Case Studies across Portuguese. Mouton de Gruyter, Berlin.

Unsworth, S., 2005. Child L2, Adult L2, Child L1: Differences and Similarities. A study on the Acquisition of Direct Object Scrambling in Dutch. PhD dissertation, Utrecht University.

White, L., 2009. Language acquisition at the interfaces. Keynote address at the Mind-Context Divide Workshop. University of Iowa, Iowa City Iowa, May 1 st 2009.

Zanuttini, R., 1997. Negation and Clausal Structure: A Comparative Study of the Romance languages. Oxford University Press, New York. 